\title{
Fournier's Gangrene in a Female Patient with Diabetes Mellitus: Report of a Case
}

\author{
Diabetes Mellitusu Olan Bir Kadın Hastada Fournier Gangreni: Bir Olgu Sunumu
}

Gökhan Aksel', Betül Akbuğa Özel², Cemil KavalCl ${ }^{2}$, Murat Muratoğlu²

'Department of Emergency Medicine, Ümraniye Training and Research Hospital, İstanbul, Turkey

2Department of Emergency Medicine, Başkent University Faculty of Medicine, Ankara, Turkey

\section{ABSTRACT}

Introduction: Fournier's gangrene is relatively uncommon condition, especially in female patients. The literature suggests that Fournier's gangrene in women may arise from vulvar or Bartholin's gland abscesses or may result from hysterectomy or episiotomy. Here, we present a female with Fournier's gangrene without a history of abscesses, hysterectomy, or episiotomy.

Case Report: A 39-year-old woman presented to the emergency department with hyperemia, edema, and pain on the perineal area. The patient had a history of diabetes mellitus and recurrent urinary tract infections. Physical examination revealed malodorousness, hyperemia, and a gangrenous necrotic surface on the mons pubis. Body temperature was $38^{\circ} \mathrm{C}$, WBC was 26,000 $\mathrm{mm}^{3}$, and C-reactive protein was $315 \mathrm{mg} / \mathrm{L}$. Pelvic computed tomography revealed a progressive subcutaneous tissue infiltration and soft tissue gas within the whole pelvic area radiating to the abdomen. Wide perineal debridement was performed, and vancomycin and clindamycin were preferred for antibiotherapy. She was discharged healthy after 20 days of hospitalization.

Conclusion: Fournier's gangrene is a serious surgical emergency with a high mortality rate. Using broad-spectrum antibiotics and extensive surgical debridement remains the cornerstone of the therapy. Although Fournier's gangrene is mostly attributed to the male gender, emergency physicians should also consider this disease in female patients who have comorbid diseases, like DM, and present with findings suggestive of infection in the perineal area.

Keywords: Fournier's gangrene, emergency department, female patient

Received: 24.04.2014 Accepted: 03.05.2014

\section{ÖZET}

Giriş: Fournier gangreni özellikle kadın hastalarda nadir görülen bir durumdur. Literatüre göre kadın hastalarda Fournier gangreni vulvar veya Bartholin absesinin ilerlemesi veya histerektomi ya da epizyotomi sonrası gelişebilir. Bu yazıda vulvar veya Bartholin absesi olmayan, histerektomi veya epizyotomi öyküsü bulunmayan Fournier gangreni olan bir kadın hastayı paylaşmayı amaçladık.

Olgu Sunumu: 39 yaşında kadın hasta acil servise perineal ve infrapubik bölgede, hiperemi, ödem ve ağrı şikayetleri ile başvurdu. Hastanın Diabetes Mellitus (DM) ve tekrarlayıcı üriner sistem enfeksiyonu öyküsü mevcuttu. Fizik muayenede mons pubis üzerinde kötü kokulu, hiperemik ve nekrotik alanlar olduğu görüldü. Vücut ısısı $38^{\circ} \mathrm{C}$, lökosit sayısı $26,000 \mathrm{~mm}^{3}$ ve C-reaktif protein $315 \mathrm{mg} / \mathrm{L}$ olarak ölçüldü. Pelvis tomografisinde progresif subkutanöz doku infiltrasyonu görüntüsü tespit edildi. Tüm pelvik alanda olan, abdomene yayılan yumuşak doku içerisinde gaz görüntüsü mevcuttu. Genel cerrahi tarafından hastaya geniş perineal debritman uygulandı. Vankomisin ve klindamisin verildi. 20 günlük hastane yatışı sonrasında hasta sağlıklı olarak taburcu edildi.

Sonuç: Fournier gangreni yüksek mortaliteye sahip, ciddi cerrahi bir acildir. Geniş spektrumlu antibiyotik uygulanmasını takiben geniş cerrahi debritman yapılması tedavinin köşe taşlarını oluşturmaktadır. Her ne kadar Fournier gangreni çoğunlukla erkek cinsiyetle ilişkilendirilmişse de, acil servis doktorları perineal bölgede enfeksiyon bulgusu ile başvuran ve immun yetersizliğe sebep olabilecek DM gibi komorbid hastalıkları olan kadın hastalarda da Fournier gangrenini düşünmelidirler.

Anahtar Kelimeler: Fournier gangreni, Acil servis, kadın hasta

Geliş Tarihi: 24.04.2014 Kabul Tarihi: 03.05.2014 


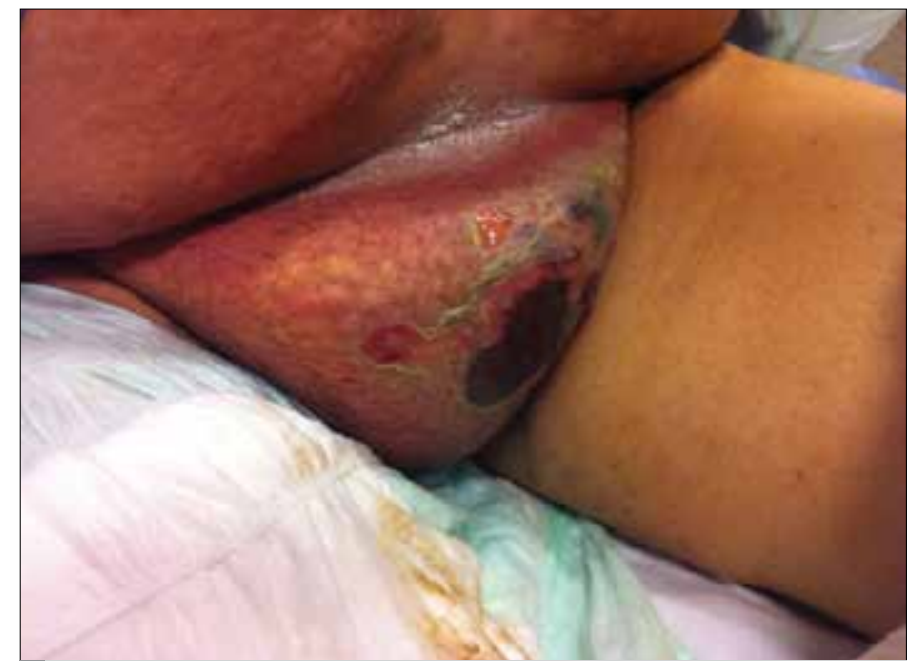

Figure 1. Hyperemia and gangrenous necrotic surface on the mons pubis of the patient

\section{Introduction}

Fournier's gangrene is a surgical emergency that is characterized by progressive necrotizing infection of the perineum or external genitalia (1). Fournier's gangrene is relatively uncommon. The overall incidence is $1.6 / 100,000$ in males, but the incidence for females is unclear. The male-to-female ratio varies from 10:1 to 42:1 in the literature $(1,2)$. This condition has also been described in children $(3,4)$. Fournier's gangrene in women may arise from vulvar or Bartholin's gland abscesses or may result from episiotomy or hysterectomy (5). In this case, we present a female who presented with Fournier's gangrene without a history of abscesses, episiotomy, or hysterectomy.

\section{Case Report}

A 39-year-old woman presented to the emergency department (ED) with hyperemia, edema and pain on the perineal and infrapubic area, especially on the mons pubis. These symptoms started 2 days ago. The patient had a history of diabetes mellitus (DM) for 15 years and recurrent urinary tract infections for nearly 10 years. She presented to a different ED 2 days ago and was discharged with a suggestion of using penicillin with a diagnosis of cellulite. Her blood pressure was 120/60 mm Hg, pulse was 100 beat/min, and body temperature was $38^{\circ} \mathrm{C}$. On her physical examination, the mons pubis was hyperemic and had a malodorous and gangrenous necrotic surface (Figure 1). White blood cell count was $26,000 \mathrm{~mm}^{3}$, and C-reactive protein was measured as $315 \mathrm{mg} / \mathrm{L}$.

The physical examination and laboratory results were suggestive of Fournier's gangrene as an initial diagnosis. The diagnosis was confirmed by pelvic computed tomography (CT), which revealed a progressive subcutaneous tissue infiltration with evidence of soft tissue gas within the whole pelvic area radiating to the abdomen (Figures 2 and 3). The patient was consulted by general surgery and initially treated with clindamycin intravenously. Wide perineal debridement was performed by surgeons under general anesthesia.

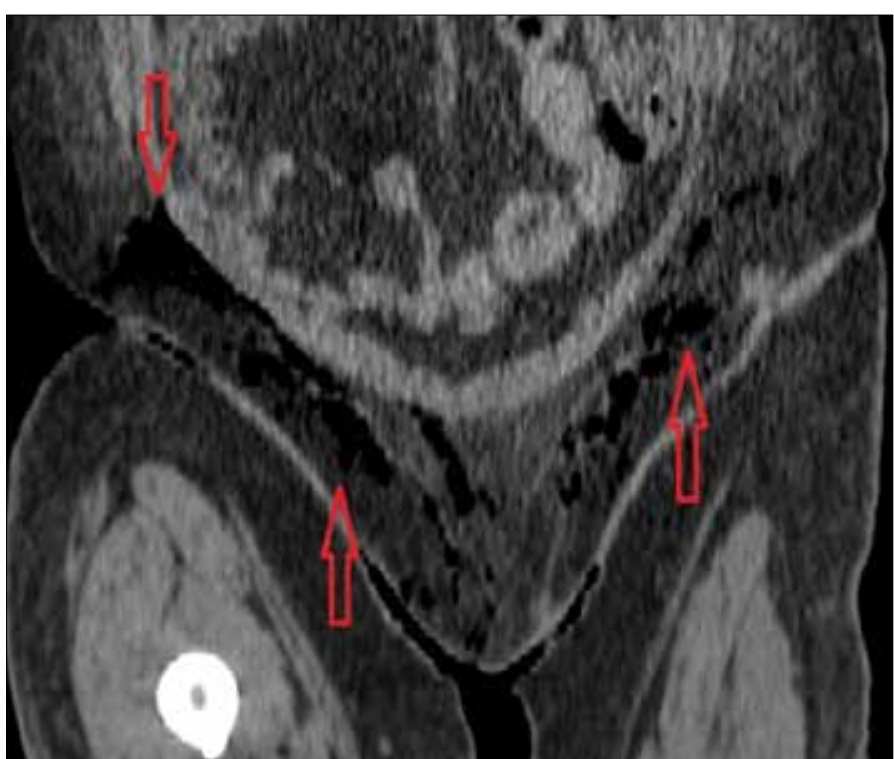

Figure 2. Computed tomography of pelvis (coronal)

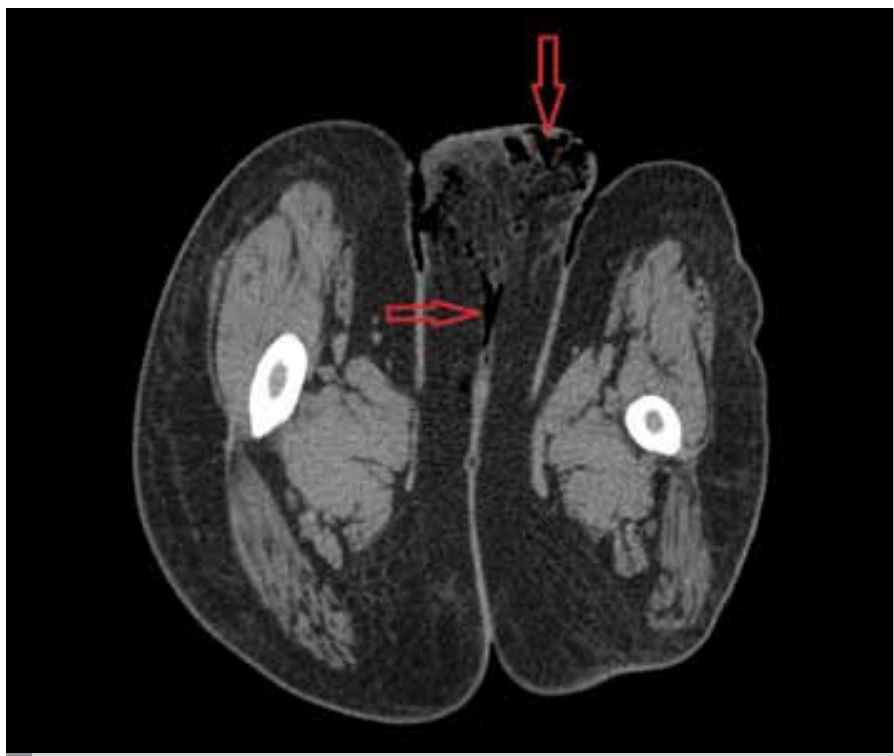

Figure 3. Computed tomography of pelvis (axial)

After detection of Staphylococcus Aureus in the wound specimens and blood cultures, vancomycin was added to the regimen. She was discharged healthy after 20 days after hospitalization.

\section{Discussion}

Fournier's gangrene was first demonstrated in 1764 by Baurienne. (6). Necrotizing soft tissue infections are identified in 3 types. Type I is polymicrobial in origin with a combination of gram-negative and gram-positive bacteria along with anaerobes. Type II infection is monomicrobial. Group A Streptococcus is the most common cause of the infection, and Staphylococcus Aureus is the second. Type II is less common and usually seen in healthy, immunocompetent patients. Some authors classify necrotizing infection caused by Vibrio vulnificusas type III, but this is not universally agreed on (7). In the 
present case, Staphylococcus Aureus was detected in the wound specimens and blood cultures.

Three main distinctive features of Fournier's gangrene are described as sudden appearance in a healthy person, usually male; absence of a definite cause; and rapid progression to gangrene (7). Many predisposing factors have been reported, including malignancy and diseases in the perianal region, local trauma, peripheral vascular disease, urethral stricture, alcohol misuse, DM, chronic steroid use, malnutrition, and HIV infection (6). These conditions usually start as a simple infection and later rapidly progress into an end-artery thrombosis in the subcutaneous tissue, leading to widespread necrosis, especially in immunocompromised persons (8). Our patient was obese, and she had a history of recurrent urinary tract infections. She had DM for 15 years, and so, she is also immunocompromised. She presented to a different ED 2 days ago with fever and hyperemia on the pubic area. She was initially misdiagnosed as cellulitis and discharged after being prescribed penicillin at the previous ED. CT and ultrasonography are the diagnostic imaging techniques used for Fournier gangrene (9). In our case, our diagnosis of Fournier's gangrene was based on the patient's clinical situation, and confirmation was done with a pelvic CT scan. Treatment of Fournier's gangrene remains the use of broad-spectrum antibiotics, followed by aggressive debridement. Despite the advanced management techniques, mortality still remains high, with an average of 6\%$74 \%$ (10). Our patient was successfully treated with clindamycin, vancomycin, and wide surgical debridement.

\section{Conclusion}

Fournier's gangrene is a serious surgical emergency and has a high mortality rate. Early diagnosis is extremely important. Broadspectrum antibiotics, followed by extensive surgical debridement, remains the cornerstone of the therapy. Although Fournier's gangrene is mostly attributed to male gender, emergency physicians should also consider this disease in female patients, especially those who have comorbid diseases, especially causing immunodeficiency, like DM, and present with findings suggestive of infection in the perineal area.

Informed Consent: None. There are not any detailed information about patient's identity. All information is anonymized.

Peer-review: Externally peer-reviewed.

Author Contributions: Concept - G.A.; Design - B.A.Ö.; Supervision - C.K.; Materials - M.M.; Data Collection and/or Processing - M.M.;
Analysis and/or Interpretation - C.K.; Literature Review - G.A.; Writer G.A.; Critical Review - C.K.

Conflict of Interest: The authors declare that there are no conflicts of interest.

Financial Disclosure: The authors declared that this study has received no financial support.

Hasta Onamı: Hayır. Hastanın kimliğini belli edecek herhangi bir detay bulunmakta olup bilgiler ve görseller anonimdir.

Hakem Değerlendirmesi: Dış bağımsız.

Yazar Katkıları: Fikir - G.A..; Tasarım - B.A.Ö.; Denetleme - C.K.; Malzemeler - M.M.; Veri toplanması ve/veya işlemesi - M.M.; Analiz ve/veya yorum - C.K.; Literatür taraması - G.A.; Yazıyı yazan - G.A..; Eleştirel İnceleme - B.A.Ö., C.K.

Çıkar Çatışması:Yazarların herhangi birçııarçatışması bulunmamaktadır.

Finansal Destek: Bu yazı ile ilişkili herhangi bir finansal destek bulunmamaktadır.

\section{References}

1. Sorensen MD, Krieger JN, Rivara FP, Broghammer JA, Klein MB, Mack CD, Wessells H. Fournier's Gangrene: population based epidemiology and outcomes. J Urol 2009; 181: 2120-6. [CrossRef]

2. Eke N. Fournier's gangrene: a review of 1726 cases. Br J Surg 2000; 87: 718. [CrossRef]

3. Adams JR Jr, Mata JA, Venable DD, Culkin DJ, Bocchini JA Jr. Fournier's gangrene in children. Urology 1990; 35: 439-41. [CrossRef]

4. Ekingen $\mathrm{G}$, Isken T, Agir H, Oncel S, Günlemez A. Fournier's gangrene in childhood: a report of 3 infant patients. J Pediatr Surg 2008; 43: e39-42. [CrossRef]

5. Czymek R, Frank P, Limmer S, Schmidt A, Jungbluth T, Roblick U, et al. Fournier's gangrene: is the female gender a risk factor? Langenbecks Arch Surg 2010; 395: 173-80. [CrossRef]

6. Mallikarjuna MN, Vijayakumar A, Patil VS, Shivswamy BS. Fournier's Gangrene: Current Practices. ISRN Surg 2012; 2012: 942437. [CrossRef]

7. Sarani B, Strong M, Pascual J, Schwab CW. Necrotizing fasciitis: current concepts and review of the literature. J Am Coll Surg 2009; 208: 279-88. [CrossRef]

8. Levenson RB, Singh AK, Novelline RA. Fournier gangrene: role of imaging. Radiographics 2008; 28: 519-28. [CrossRef]

9. Kavalci C, Cevik Y, Durukan P, Temizoz O. Fournier's gangrene. Intern Emerg Med 2009; 4: 433-4. [CrossRef]

10. Headley AJ. Necrotizing soft tissue infections: a primary care review. Am Fam Physician 2003; 68: 323-8. 